\title{
PENGARUH KUALITAS AIR TERHADAP PRODUKSI RUMPUT LAUT (Kappaphycus alvarezii)
}

\author{
Andi Ichsan Nur1), Husain Syam²), Patang2) \\ ${ }^{1}$ Alumni Program Studi Pendidikan Teknologi Pertanian \\ ${ }^{2}$ dan ${ }^{3}$ Dosen PTP FT UNM
}

\begin{abstract}
The study aims to determine the effect of water quality on the production of seaweed (Kappaphycus alvarezii). This study was an experimental study using a completely randomized design (CRD). There are three treatments, treatment $A(50 \mathrm{~m})$, treatment $B(500 \mathrm{~m})$, treatment $C(1000 \mathrm{~m})$ and a control consisting of three replications. The research variables were observed include the production and quality of the sea water. The analysis technique used in this research is the analysis of variance were processed using SPSS version 20. The results showed that the location most suitable planting sea grass is at a spacing of 500 meters from the river mouth to the value of the highest average production of $88500 \mathrm{~g}(88,5 \mathrm{~kg})$ while the water quality such as salinity, $\mathrm{pH}$, temperature, turbidity, phosphates and dissolved oxygen, still within acceptable limits for the growth and production of seaweed (Kappaphycus alvarezii).
\end{abstract}

Keywords: Water Quality, Growth, Production, Seaweed

\section{PENDAHULUAN}

Kabupaten Bulukumba merupakan pusat incubator rumput laut di mana kluster pengembangannya tersebar di seluruh kecamatan. Salah satu kecamatan yang menjadi sentra pengembangan rumput laut adalah Kecamatan Bontobahari. Wilayah ini memiliki luas 100,50 $\mathrm{km}^{2}$ dengan panjang garis pantai $74 \mathrm{~km}^{2}$ yang terbagi kedalam 12 desa/kelurahan diantaranya Kelurahan Sapolohe dengan luas wilayah $15.74 \mathrm{~km}^{2}$. Dengan kondisi wilayahnya yang terletak $<50 \mathrm{~m}$ dari permukaan laut, desa ini menjadi salah satu sentra pengembangan rumput laut yang cukup maju di Kabupaten Bulukumba (Laporan Tahunan Kementerian Kelautan dan perikanan, 2013).

Rumput laut merupakan salah satu komoditiperikanan budidayayang saat ini sementara digalakkan oleh pemerintah guna meningkatkan devisa negara. Komoditi ini bahkan telah ditetapkan sebagaikomoditas utamadalamprogram

revitalisasiperikanansejak tahun 2005, sehingga dibutuhkan budidaya secara cepat dan tepat dalam melayani permintaan produksi secara kuantitas, kualitas dan kontinuitas dengan menggunakan paket teknologisederhana yangdapatdigunakanolehpembudidaya (Joppy, 2015).

Pemilihan lokasi yang tepat merupakanfaktoryangpentingdalam menentukan kelayakan usahabudidaya rumputlaut.Faktorutamakeberhasilan kegiatan budidaya rumputlautadalah pemilihan lokasi yang tepat.Di antara faktor lingkungan tersebut adalah ketersediaancahaya, suhu,salinitas, arusdanketersediaannutrien(Lobban andHarrison, 1997). Selanjutnya, Akib (2015) menyatakan faktor fisika, kimia 
dan biologi dari suatu perairan menjadi salah satu penentu keberhasilanbudidayarumput laut. Meningkatnya produksi rumput laut melalui kegiatan budidaya pada lahan-lahan yang ada turut menentukan kondisi kualitas air untuk mendukung keberlangsungan kehidupan budidaya rumput laut pada suatu perairan. Rumput laut merupakan salah satu tanaman yang dapat dibudidayakan di perairan pantai (laut), maupun di perairan payau (muara). Diduga kualitas air laut, suhu, kekeruhan, salinitas, pH air, oksigen terlarut, fosfat, dan tingkat kadar garam air laut sangat berpengaruh terhadap produksi rumput laut (Patang dan Yunarti, 2009). Kadar garam yang sesuai untuk pertumbuhan rumput laut berkisar 28-35 ppt. Salinitas yang baik berkisar antara 28 - 34 ppt dengan nilai optimum adalah 33 ppt. Untuk memperoleh perairan dengan salinitas demikian, perlu dihindari lokasi yang berdekatan dengan muara sungai. Air laut yang diperlukan untuk budidaya rumput laut penting diketahui agar tidak timbul masalah yang dapat menghambat usaha itu sendiri dan mempengaruhi mutu hasil yang dikehendaki (Tambaru dan Samawi, 1996). Tujuan penelitian adalah untuk mengetahui pengaruh kualitas air laut terhadap pertumbuhan dan produksi rumput laut (Kappaphycus alvarezii).

\section{METODOLOGI}

\section{Waktu dan Tempat Penelitian}

Penelitian ini dilaksanakan pada Bulan Juni sampai Juli 2015 di daerah budidaya rumput laut. Kelurahan Sapolohe, Kecamatan Bontobahari, Kabupaten Bulukumba.

\section{Jenis Penelitian}

$\begin{array}{lrr}\text { Jenis } & \begin{array}{c}\text { penelitian } \\ \text { eksperimen, }\end{array} & \text { adalah } \\ \text { penelititi }\end{array}$ menggunakan metode Rancangan Acak Lengkap (RAL). Pengacakan dilakukan dengan menggunakan tabel angka random 3 perlakuan yaitu $500 \mathrm{~m}$ dari muara sungai dan $1000 \mathrm{~m}$ dari muarah sungai dengan kontrol $50 \mathrm{~m}$ dari pantai dan ulangan sebanyak 3 kali. Metode yang digunakan dalam penentuan tempat/denah adalah metode undian, seperti pada Tabel 1.

\section{Tabel 1. Denah penelitian}

\begin{tabular}{|l|l|l|}
\hline A1 & B2 & A3 \\
\hline B1 & C2 & B3 \\
\hline C1 & A1 & C3 \\
\hline
\end{tabular}

Sumber : Patang dan Yunarti, 2013

Keterangan :

$A=$ Lokasi penanaman $500 \mathrm{~m}$ dari muara dan dilakukan tiga kali pengulangan.

$B=$ Lokasi penanaman $1000 \mathrm{~m}$ dari muara dan dilakukan tiga kali pengulangan.

$\mathrm{C}=$ Lokasi penanaman $50 \mathrm{~m}$ dari pantai dan dilakukan tuga kali ulangan.

Masing-masing perlakuan diulang sebanyak 3 kali. Model linier yang digunakan adalah Rancangan Acak Lengkap (RAL)(Sulistijo, 1980)

$$
Y i j=m+t i+e i j
$$

$i=$ Perlakuan $(\mathrm{K} 1, \mathrm{~K} 2, \mathrm{~K} 3)$

$j=$ Ulangan (U1, U2, U3)

Keterangan:

$Y i j=$ nilai pengamatan pada perlakuan ke-i

(penanaman dengan pemberianjarak tanam taraf ke-i ulangan ke-j)

$m=$ nilai rataan 
$\mathrm{Ti}=$ pengaruh perlakuan ke-I (penanaman dengan pemberianjarak tanam taraf ke-i ulangan ke-j)

हij = galat percobaan pada perlakuan ke-i ulangan ke-j (penanaman dengan pemberian jarak tanam taraf ke-iulangan ke- j)

\section{Alat dan Bahan}

Alat dan Bahan yang digunakan serta kegunaannya masing-masing terdapat pada Tabel 2 dan Tabel 3.

Tabel 2.Alat yang digunakan dalam penelitian serta kegunaannya masing-masing

\begin{tabular}{|c|c|}
\hline ALAT & KEGUNAAN \\
\hline Thermometer & mengukur parameter suhu \\
\hline Handrefraktometer & $\begin{array}{l}\text { mengukur parameter } \\
\text { salinitas }\end{array}$ \\
\hline Botol Aqua & menyimpan sampel air \\
\hline Tabung reaksi & $\begin{array}{l}\text { tempat mencampur } \\
\text { larutan }\end{array}$ \\
\hline Turbidimeter & $\begin{array}{l}\text { mengukur parameter } \\
\text { kekeruhan }\end{array}$ \\
\hline Botol oksigen & $\begin{array}{l}\text { megukuran oksigen } \\
\text { terlarut }\end{array}$ \\
\hline $\begin{array}{l}\text { Pipet tetes } \\
\text { Pengaduk } \\
\text { Pemanas } \\
\text { Kulkas } \\
\text { Gelas penutup } \\
\text { Kertas lakmus }\end{array}$ & $\begin{array}{l}\text { mengambil larutan } \\
\text { mengaduk } \\
\text { memanaskan } \\
\text { mendinginkan sampel air } \\
\text { menutup 28rlenmeyer } \\
\text { mengukur pH air }\end{array}$ \\
\hline Styrofoam & $\begin{array}{l}\text { menyimpan botol yang } \\
\text { berisi air }\end{array}$ \\
\hline perahu & Sebagai alat bantu I \\
\hline patok & $\begin{array}{l}\text { Penanda titik pengambilan } \\
\text { sampel }\end{array}$ \\
\hline Kertas label & Penanda sampel air laut \\
\hline Jangkar & $\begin{array}{l}\text { Sebagai penahan tempat } \\
\text { pembibitan }\end{array}$ \\
\hline
\end{tabular}

Sumber : (Kamlasi, 2008).
Tabel 3. Bahan yang digunakan dalam penelitian serta kegunaannya masingmasing

\begin{tabular}{ll}
\hline \multicolumn{1}{c}{ BAHAN } & \multicolumn{1}{c}{ KEGUNAAN } \\
\hline Rumput laut & Sebagai bahan utama \\
Tali & Tempat pembibitan \\
Pelampung & Sebagai pelampung \\
\hline \multicolumn{2}{c}{ Sumber : (Kamlasi, 2008). }
\end{tabular}

Bahan yang digunakan dalam penelitian ini yaitu rumput laut dan sampel air laut yangdiambil di lokasi penelitian. Selain itu, akuadesdan indikator ferroin digunakan untuk mengawetkan sampel air laut yang disimpan dalam styrofom (Kamlasi 2008).

\section{Prosedur Penelitian}

Pada penelitian ini dilakukan budidaya rumput laut di sekitar muara sungai. Penempatan lokasi budidaya yaitu dengan jarak $50 \mathrm{~m}$ (kontrol) dari muara sungai, $500 \mathrm{~m}$ dari muara sungai dan $1000 \mathrm{~m}$ dari muara sungai. Beberapa faktor yang perlu diperhatikan dalam budidaya rumput laut jenis Kappaphycus alvarezii yaitu :

\section{Pemilihan Lokasi}

Lokasi untuk melakukan penelitian ini terletak di Kabupaten Bulukumba, Kecamatan Bontobahari, Kelurahan Sapolohe. Beberapa persyaratan yang diperhatikan terkait dengan lokasi yakni : perairan cukup tenang, terlindung dari pengaruh angin dan ombak, faktor lain yang juga perlu diperhatikan adalah kualitas air, akses tenaga kerja, perizinan, dan sebagainya (Patang dan Yunarti, 2013). 


\section{Menyiapkan Areal Budidaya}

Setelah lokasi sudah dipastikan cukup baik, maka dilakukan persiapan lahan sebagai berikut (Patang dan Yunarti, 2013) :

1. Membersihkan dasar perairan lokasi budidaya dari rumput-rumput laut liar dan tanaman pengganggu lain yang biasa tumbuh subur.

2. Membersihkan calon lokasi dari karang, batu, bintang laut, bulu babi, maupun hewan predator lainnya.

3. Menyiapkan tempat penampungan benih (seed bin), yang terbuat dari kerangka besi dan berjaringdari rotan, ukurannya $2 \times 2 \times 1.5$ meter.

\section{Metode Budidaya yang Digunakan Tali Tunggal Apung (long line)}

Metode ini merupakan bentuk dari metode tali tunggal apung. Maka dalam penelitian ini akan dilakukan pembudidayaan rumput laut ditiga tempat yang berbeda yaitu $50 \mathrm{~m}$ dari muara sungai, $500 \mathrm{~m}$ dari muara sungai, $1000 \mathrm{~m}$ dari muara sungai, dan lokasi budidaya yang umum dilakukan oleh petani sebagai kontrol. Metode ini tidak lagi digunakan kayu pancang, tetapi diganti dengan pelampung. Metode ini berupa bentangan tali sepanjang 25 meter dimana setiap bentangan tali diberi bibit rumput laut sebanyak $35 \mathrm{~kg}$ (Patang dan Yunarti, 2013).

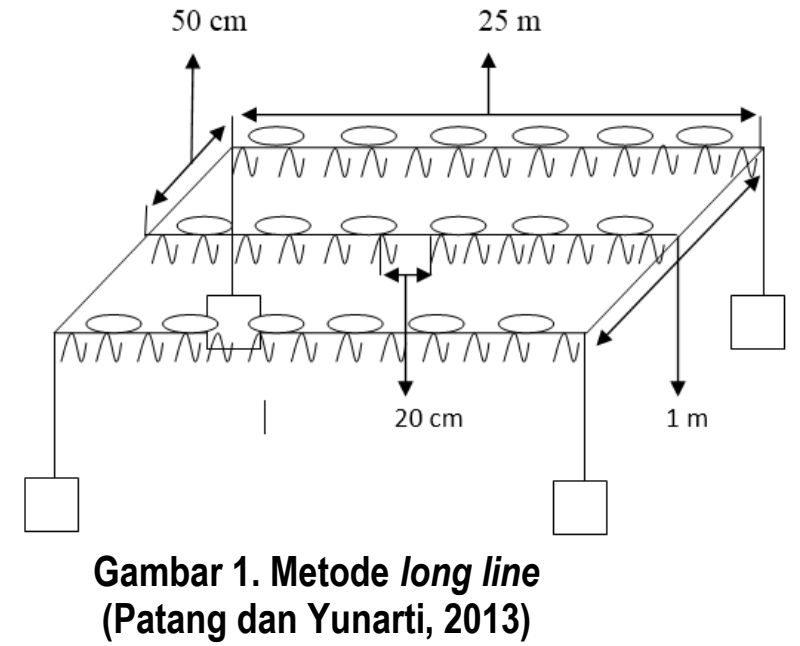

Keterangan :

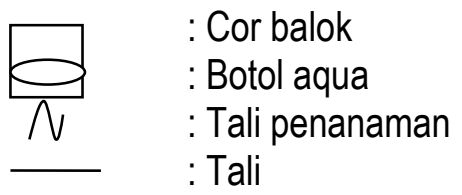

Penyediaan bibit

Bibit rumput laut dapat berasal dari stok alam atau dari hasil budidaya.Pengadaan bibit untuk budidaya rumput laut dilakukan dengan vegetatif (sistem steak) serta tidak menutup kemungkinan pengadaannya dilakukan dengan cara generatif (sistem pembiakan spora). Mengingat kualitas dan kuantitas produksi rumput laut ditentukan oleh bibit rumput lautnya, maka pengadaan dan pemilihan bibit harus dilakukan secara cermat (Patang dan Yunarti, 2013).

Penanaman Bibit

Bibit yang akan ditanam adalah thallus yang masih muda dan berasal dari ujung thallus tersebut. Saat yang baik untuk penebaran maupun penanaman benih adalah pada saat cuaca teduh (tidak mendung) dan yang paling baik adalah pagi hari atau sore 
hari menjelang malam (Patang dan Yunarti, 2013).

\section{Perawatan Selama Pemeliharaan}

Seminggu setelah penanaman, bibit yang ditanam harus diperiksa dan dipelihara dengan baik melalui pengawasan yang teratur dan kontinyu. Bila kondisi perairan kurang baik, seperti ombak yang keras, angin kencang (hujan/kemarau), perlu pengawasan 2-3 hari sekali (Patang dan Yunarti, 2013).

\section{Pengukuran Pertumbuhan}

Pengukuran pertumbuhan di lokasi dangan cara mengambil sampel rumput laut, lalu ditimbang. Pengukuran pertumbuhan di lokasi dilakukan setiap 7 hari dan pada akhir penelitian (Patang dan Yunarti, 2013).

\section{Pemanenan}

Pemanenan dapat dilakukan bila rumput laut telah berumur 1 bulan, yakni sekitar 30 hari setelah penanaman bibit (waktu pemeliharaan selama 1 bulan). Cepat tidaknya pemanenan tergantung metode dan perawatan yang dilakukan setelah bibit ditanam (Patang dan Yunarti, 2013).

\section{Penghitungan Hasil Produksi}

\footnotetext{
Perhitungan hasil produksi dilakukan dengan cara menimbang seluruh rumput laut yang di hasilkan dari tiga perlakuan yaitu jarak tanam $50 \mathrm{~m}$, $500 \mathrm{~m}$ dan $1000 \mathrm{~m}$ dari muara sungai. Dengan membandingkannya maka kita dapat memporoleh data yang valit, sehingga kita dapat menyimpulkan bahwa ada atau tidak pengaruh kadar
}

garam terhadap produksi rumput laut (Patang dan Yunarti, 2013).

\section{Pengambilan Sampel}

Pengambilan sampel air laut dilakukan dengan interval 7 hari selama penelitian (1 bulan) atau sampel diambil 1 kali dalam 1 minggu. Total pengambilan sampel adalah sebanyak 5 kali. Sampel diambil pada kedalaman yang sama yaitu $50 \mathrm{~cm}$ dari permukaan laut dengan memasukan botol ke dalam air laut sampai terisi penuh (Patang dan Yunarti, 2013).

Untuk pengukuran oksigen terlarut, pengambilan sampel digunakan botol terang, pengukuran BOD digunakan botol gelap dan pengukuran parameter lainnya kecuali intensitas cahaya dan suhu, digunakan botol aqua. Pengambilan sampel pertama kalidilakukan di daerah budidaya rumput laut yang jauh dari muarah, setelah itu di daerah budidaya rumput laut yang dekat dengan muara. Jarak antara titik pengambilan sampel daerah budidayarumput laut yang jauh dari muarah dengan daerah budidaya rumput laut yang dekat dengan muarah hampir $500 \mathrm{~m}$. Sebelum pengambilan sampel awal, terlebih dahulu dilakukan pemasangan patok pada masing-masing lokasi penelitian sebagai penanda untuk pengambilan sampel selanjutnya. Untuk sampai ke titik pengambilan sampel digunakan alat bantu yaitu perahu (sampan). Sampel air disimpan dalam Styrofoam untuk dibawa ke Laboratorium Kualitas Air Jurusan Budidaya Perikanan Politeknik Pertanian Negeri Pangkajene Kepulauan (Patang dan Yunarti, 2013). 


\section{Parameter yang Diamati}

Parameter yang diukur yaitu suhu, kekeruhan, salinitas, $\mathrm{pH}$ air, oksigen terlarut (DO) dan fosfat. Pengukuran parameter suhu dan kekeruhan di lakukan di lokasi penelitian. Sedangkan untuk parameter salinitas, $\mathrm{pH}$ air, oksigen terlarut (DO) dan fosfat diukur di Laboratorium Kualitas Air Jurusan Budidaya Perikanan Politeknik Pertanian Negeri Pangkajene Kepulauan.

Suhu

Suhu air diukur dengan menggunakan thermometer yaitu dengan caramencelupkan sampai 3/4 panjang thermometer kedalam air. Setelah itu didiamkan beberapa menit. Kemudianmenentukan nilai suhu yang ditunjukkan pada thermometer tersebut danmencatat hasilnya (Tambaru dan Samawi, 1996).

\section{Kekeruhan}

Pengukuran parameter kekeruhan dilakukan dengan menggunaan secchi disk(Patang dan Yunarti, 2013).

1. Celupkan secchi disk kedalam air laut, kemudian perhatikan kenampakannya.

2. Berikan tanda pada tali secchi disk sesuai dengan kenampakan secchi disk.

3. Ukur panjang kedalam tali secchi disk, kemudian hasilnya dicatat.

\section{Salinitas (kadar garam)}

Salinitas diukur dengan alat hand refraktometer (Tambaru dan Samawi, 1996)
1. Air sampel diambil secukupnya, lalu diteteskan pada kaca depanrefraktometer.

2. Kemudian diamati melalui lensa belakang.

3. Penunjukan nilai salinitas pada alat tersebut, dicatat.

\section{pH Air}

$\mathrm{pH}$ air diukur dengan menggunakan $\mathrm{pH}$ meterdengancara air sampel diambil secukupnya kedalam botol, lalu $\mathrm{pH}$ meter kurang akurat dicelupkanke dalam air sampel. Nilai $\mathrm{pH}$ meter pada cover tersebut dicatat (Tambaru dan Samawi, 1996).

\section{Oksigen Terlarut (DO)}

Parameter oksigen terlarut diukur dengan yang dilakukan Tambaru dan Samawi (1996), yaitu:

1. Sampel air dimasukkan ke dalam botol oksigen lalu ditutup (jangan ada gelembung),

2. Ditambahkan $0,5 \mathrm{ml} \mathrm{MnSO4}$ dan 0,5 $\mathrm{KI}$, ditutup rapat-rapat dan dibolakbalik \pm 20 kali, setelah itu dibiarkan beberapa menit hingga endapan coklat terbentuk dengan sempurna.

3. Ditambahkan $1 \mathrm{ml} \mathrm{H} 2 \mathrm{SO} 4$ pekat kemudian diaduk dengan cara yang sama hingga semua endapan larut (kalau masih ada endapan, ditambahkan lagi $\mathrm{H} 2 \mathrm{SO} 4$ pekat $\pm 0,5$ $\mathrm{ml})$, warna kuning.

4. Sampel yang ada dalam botol dituang ke dalam erlemeyer kemudian ditambahkan \pm 5 tetes indikator amilum (warna biru),

5. Dititrasi dengan $\mathrm{Na} 2 \mathrm{~S} 2 \mathrm{O} 30,025 \mathrm{~N}$ hingga tidak berwarna dan dicatat.

6. Perhitungan :1000 mlO2 $=X \mathrm{ml}$ Na2S2O3 0,025 N X 0,16 ml sampel. 


\section{Fosfat}

Pengukuran parameter fosfat sesuai yang dilakukan oleh Tambaru dan Samawi (1996), yaitu:

1. Sampel air dipipet sebanyak $2 \mathrm{ml}$ kemudian dimasukkan ke dalam tabung reaksi,

2. Ditambahkan $2 \mathrm{ml}$ asam borat $1 \%$,

3. Selanjutnya ditambahkan $3 \mathrm{ml}$ larutan pengoksid,

4. Dikocok dan dibiarkan selama 1 jam sehingga terjadi warna biru dandianalisis pada spektofotometer. Kepekaan warna tergantung pada panjang gelombang $650 \mathrm{~nm}$ (absorbance).

\section{Analisis Data}

Pengaruh kualitas air terhadap produksi rumput laut dilakukan menggunakan analisis regresi yang diolah dengan menggunakan program pengolahan data SPSS versi 20.

\section{HASILDANPEMBAHASAN}

\section{Pertumbuhan dan Produksi}

Hasil pengukur pertumbuhan rumput laut selama penelitian dapat dilihat pada Gambar 2. Hasil pengukuran rumput laut menunjukkan perlakuan jarak tanam $500 \mathrm{~m}$ menghasilkan berat pertumbuhan rumput laut tertinggi yaitu 231,7 gram pada minggu ke-2. Perlakuan jarak tanam $1000 \mathrm{~m}$ menghasilkan berat rumput laut terendah dilihat dari segi pertumbuhan setiap minggunya.

Berdasarkan penelitian yang telah dilakukan dengan mengamati dan mengukur berat rumput laut yang dilakukan pada hari ke-28, rata-rata peningkatan produksi rumput laut pada perlakuan $50 \mathrm{~m}, 500 \mathrm{~m}$ dan $1000 \mathrm{~m}$ dapat dilihat pada Gambar 3. Pada awal penebaran, setiap perlakuan ditebari bibit rumput laut dengan jumlah tebar yang sama sebesar $35000 \mathrm{~g}$, dan setelah dilakukan penelitian selama 28 hari diperoleh produksi tertinggi pada jarak tanam $500 \mathrm{~m}$ dari muara sungai dengan jumlah produksi sebesar 84667 $\mathrm{g}$, disusul perlakuan $50 \mathrm{~m}$ dari muara sungai sebesar $76533 \mathrm{~g}$, dan produksi terendah pada perlakuan $1000 \mathrm{~m}$ dari muara sungai yaitu sebesar $72700 \mathrm{~g}$. Hal ini diduga disebabkan karna tingginya kandungan fosfat pada perlakuan $500 \mathrm{~m}$ dari muarah sungai yaitu $0.00902 \mathrm{ppm}$.



Gambar 2. Rata-rata berat rumput laut pada jarak tanam yang berbeda 


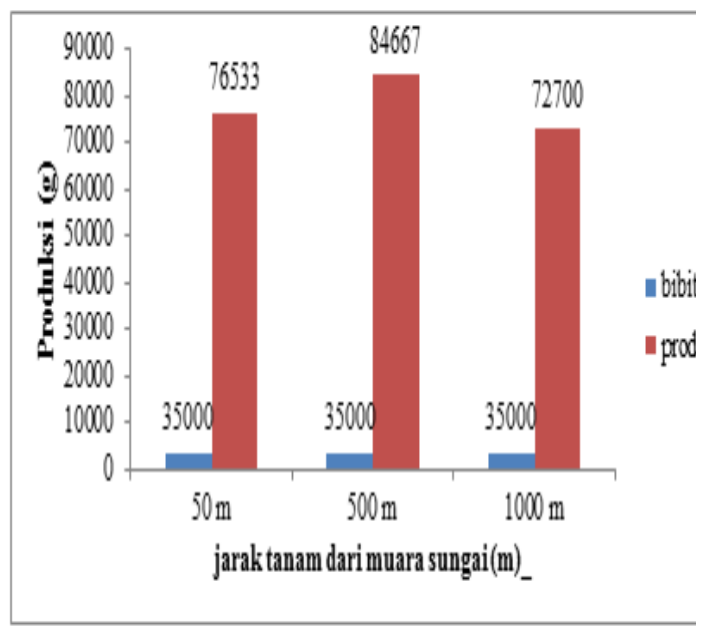

\section{Gambar 3. Hasil pengukuran produksi rumput laut selama penelitian}

Hasil pengukuran pertumbuhan rumput laut menunjukan bahwa pada jarak tanam $50 \mathrm{~m}$ dari muara sungai, rumput laut yang dibudidayakan dari minggu nol sampai minggu pertama mengalami pertumbuhan yang signifikan. Hal ini sesuai dengan hasil penimbangan rumput laut, dimana dari hasil tersebut diperoleh nilai berat antara minggu nol sampai minggu pertama yaitu $37 \mathrm{~g}$, pada minggu II berat rumput laut mengalami peningkatan yang sangat signifikan sebasar $205 \mathrm{~g}$, pada minggu III berat rumput laut mengalami peningkatan sebesar $37 \mathrm{~g}$, sedangkan pada minggu ke IV berat rumput laut mengalami peningkatan sebesar $60 \mathrm{~g}$. Hal ini disebabkan adanya faktor yang menyebabkan pertumbuhan rumput laut mengalami peningkatan seperti kualitas air yang masih dalam kisaran yang layak. Pertumbuhan yang belum maksimal disebabkan adanya penyakit, serta adanya organisme penganggu yang memangsa rumput laut.

Hasil pertumbuhan rumput laut menunjukan bahwa pada jarak tanam $500 \mathrm{~m}$ dari muara sungai yang dibudidayakan dari minggu nol sampai minggu pertama mengalami peningkatan pertumbuhan, hal ini sesuai dengan hasil penimbangan rumput laut, dimana dari hasil tersebut diperoleh nilai berat antara minggu nol sampai minggu pertama yaitu $55 \mathrm{~g}$, pada minggu II berat rumput laut mengalami peningkatan yang sangat signifikan sebesar $231 \mathrm{~g}$, pada minggu III berat rumput laut mengalami peningkatan $47 \mathrm{~g}$, sedangkan pada minggu ke IV berat rumput laut mengalami peningkatan $69 \mathrm{~g}$. Hal ini disebabkan adanya faktor yang menyebabkan pertumbuhan rumput laut mengalami peningkatan seperti kualitas air.

Hasil pertumbuhan rumput laut menunjukan bahwa pada jarak tanam $1000 \mathrm{~m}$ dari muara sungai yang dibudidayakan dari minggu nol sampai minggu pertama mengalami peningkatan pertumbuhan, yakni dibuktikan dengan hasil penimbangan rumput laut, dimana dari hasil tersebut diperoleh nilai berat antara minggu nol sampai minggu pertama yaitu $30 \mathrm{~g}$, pada minggu II berat rumput laut mengalami peningkatan yang sangat signifikan sebesar $212 \mathrm{~g}$, pada minggu III berat rumput laut mengalami peningkatan sebesar $5 \mathrm{~g}$, sedangkan pada minggu ke IV berat rumput laut mengalami peningkatan yang signifikan sebesar $73 \mathrm{~g}$. Peningkatan yang tidak maksimal disebabkan adanya penyakit, serta adanya organisme penganggu yang memangsa rumput laut.

\section{Kualitas Air}

Hasil pengujian analisis menunjukkan data kualitas air berpengaruh terhadap produksi rumput laut. Hal ini disebabkan karena parameter salinitas (ppt), pH, oksigen, $\mathrm{PO}_{4}$, suhu dan kekeruhan memberikan 
kontribusi yang sangat berpengaruh terhadap laju pertumbuhan dan produksi rumput laut.

\section{a. Salinitas}

Hasil penelitian yang telah dilakukan dengan mengamati salinitas selama empat minggu dengan jarak tanaman berbeda dapat dilihat pada Gambar 4. Hasil penelitian menunjukkan perbedaan rata-rata salinitas dari minggu ke-0 sampai minggu ke-4, rata-rata salintas yang masih berada dalam kisaran yang layak ditunjukkan pada jarak tanaman $50 \mathrm{~m}$, dan $500 \mathrm{~m}$ pada pengamatan minggu ke-2.



\section{Gambar 4. Hasil pengukuran salinitas air laut selama penelitian}

Salinitas pada daerah budidaya rumput laut yaitu $50 \mathrm{~m}, 500 \mathrm{~m}$ dan 1000 $\mathrm{m}$ dari muara sungai menunjukkan perbedaan yang signifikan. Hasil uji laboratorium menunjukkan bahwa jarak tanam $50 \mathrm{~m}$ dari muara mengandung rata-rata salinitas $15,8 \mathrm{ppt}$, jarak tanam $500 \mathrm{~m}$ dari muara mengandung rata-rata salinitas 21,67 ppt, dan jarak tanam 1000 $\mathrm{m}$ dari muara mengandung rata-rata salinitas 14,6 ppt. Kondisi salinitas yang baik untuk pertumbuhan rumput laut yaitu berkisar antara 15-35 ppt (Aslan, 1999). Hal ini menunjukkan bahwa lokasi yang ideal untuk melakukan budidaya rumput laut adalah pada jarak tanam 50 $\mathrm{m}$ dan $500 \mathrm{~m}$ dari muarah sungai. Kisaran salinitas yang terukur selama penelitian di kedua lokasi tersebut masih dalam kisaran yang dapat ditolerir sehingga mampu mendukung pertumbuhan rumput laut.

Hasil analisis sidik ragam salinitas menunjukkan adanya pengaruh sangat nyata pada perlakuan jarak tanam $50 \mathrm{~m}$ dan $500 \mathrm{~m}$ dari muara sungai. Keadaan ini didukung oleh data kualitas air selama penelitian yang cukup mendukung salinitas air laut.

\section{b. $\mathrm{pH}$}

Perlakuan jarak tanam memberi pengaruh terhadap nilai $\mathrm{pH}$ air. Perubahan nilai $\mathrm{pH}$ disajikan pada Gambar 5. Hasil penelitian yang dilakukan menunjukkan nilai $\mathrm{pH}$ air seluruh perlakuan masih dalam batas toleransi untuk budidaya rumput laut jenis Kappaphycus alfarezii baik pada jarak 50 m, 500 m, maupun $1000 \mathrm{~m}$ dari muara sungai. Hal ini menunjukkan jarak tanam yang dilakukan memberikan kontribusi terhadap tingkat keasaman air dan berpengaruh terhadap produksi pertumbuhan rumput laut. 


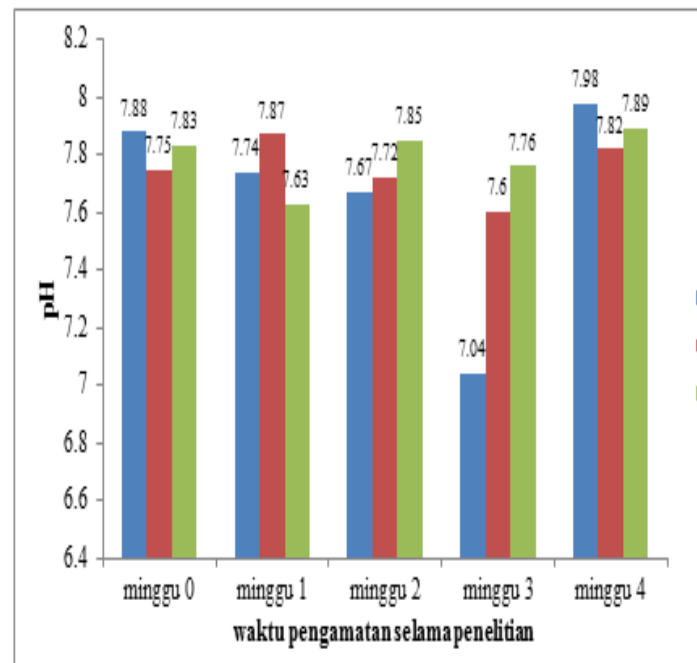

Gambar 5. Hasil pengukuran pH air laut

Derajat Keasaman (pH) pada daerah budidaya rumput laut yaitu $50 \mathrm{~m}$, $500 \mathrm{~m}$ dan $1000 \mathrm{~m}$ dari muara sungai tidak menunjukkan perbedaan yang signifikan. Hasil uji pada lokasi penelitian menunjukkan bahwa jarak tanam $50 \mathrm{~m}$ dari muara sungai mengandung rata-rata $\mathrm{pH} 7,67$, jarak tanam $500 \mathrm{~m}$ dari muara mengandung rata-rata $\mathrm{pH} 7,75$, dan jarak tanam $1000 \mathrm{~m}$ dari muara mengandung rata-rata $\mathrm{pH} 7,79$. Menurut pendapat Soesono (1988/1989) bahwa pengaruh bagi organisme sangat besar dan penting, kisaran $\mathrm{pH}$ yang kurang dari 6,5 akan menekan laju pertumbuhan bahkan tingkat keasamannya dapat mematikan dan tidak ada laju reproduksi sedangkan pH 6,5-9 merupakan kisaran optimal dalam suatu perairan.

Hal ini menunjukkan bahwa ketiga lokasi tersebut ideal untuk melakukan budidaya rumput laut. Hasil analisis sidik ragam derajat keasaman menunjukkan adanya pengaruh sangat nyata pada perlakuan jarak tanam $50 \mathrm{~m}, 500 \mathrm{~m}$ dan $1000 \mathrm{~m}$ dari muara sungai. Keadaan ini didukung oleh data kualitas air selama penelitian yang cukup mendukung derajat keasaman air laut.

\section{c. Oksigen Terlarut (DO)}

Hasil penelitian yang telah dilakukan memperoleh rata-rata oksigen terlarut berbeda-beda, hasil rata-rata dapat dilihat pada Gambar 6.

Hasil penelitian menunjukkan oksigen yang paling mendekati kisaran layak untuk produksi rumput laut ditunjukkan pada jarak tanam $1000 \mathrm{~m}$ dari muara sungai pada minggu ke-1.

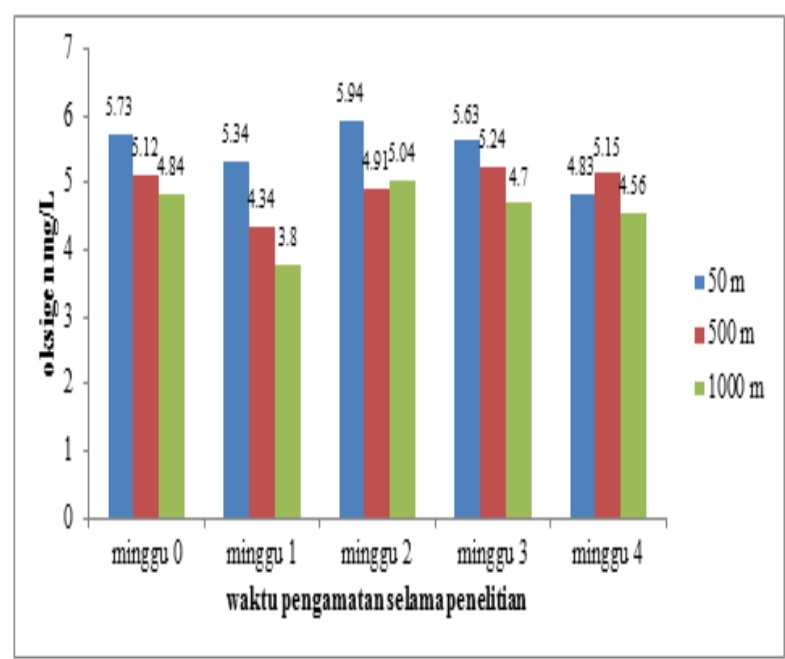

\section{Gambar 6. Hasil pengukuran oksigen terlarut air laut}

Oksigen Terlarut (DO) pada daerah budidaya rumput laut yaitu $50 \mathrm{~m}$, $500 \mathrm{~m}$ dan $1000 \mathrm{~m}$ dari muara sungai tidak menunjukkan perbedaan yang signifikan. Hasil uji pada lokasi penelitian menunjukkan bahwa jarak tanam $50 \mathrm{~m}$ dari muara mengandung rata-rata DO 5,494 , jarak tanam $500 \mathrm{~m}$ dari muara mengandung rata-rata DO 4,952, dan jarak tanam $1000 \mathrm{~m}$ dari muara mengandung rata-rata DO 4,475. Fardiaz (1992), menyatakan bahwa kejenuhan oksigen dalam air dipengaruhi oleh suhu air, semakin tinggi suhu maka konsentrasi oksigen terlarut semakin turun. 
Hal ini menunjukkan bahwa ketiga lokasi tersebut ideal untuk melakukan budidaya rumput laut. Hasil analisis sidik ragam oksigen terlarut menunjukkan adanya pengaruh sangat nyata pada perlakuan jarak tanam $50 \mathrm{~m}$ dan $500 \mathrm{~m}$ dari muara sungai. Keadaan ini didukung oleh data kualitas air selama penelitian yang cukup mendukung oksigen terlarut.

\section{d. Fosfat $\left(\mathrm{PO}_{4}\right)$}

Hasil analisis kandungan fosfat yang telah dilakukan menunjukkan perbedaan terhadap jarak tanam yang diberikan. Hasil ini juga menunjukkan nilai optimum untuk perairan dalam meningkatkan produksi rumput laut, dimana pada jarak tanam $50 \mathrm{~m}, 500 \mathrm{~m}$ dan $1000 \mathrm{~m}$ dari muara sungai, memberikan kontribusi terhadap peningkatan produksi rumput laut terkait dengan unsur hara fosfat (Gambar 7).

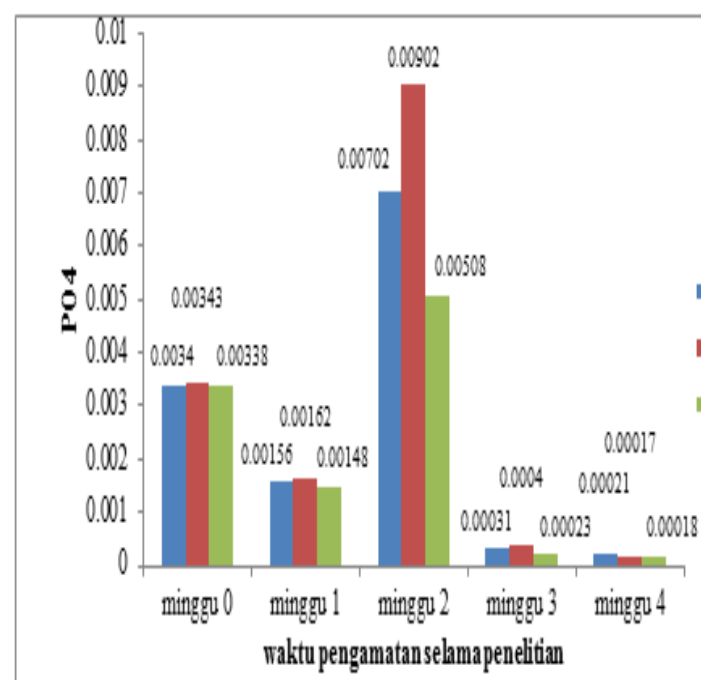

\section{Gambar 7. Hasil pengukuran fosfat air laut}

Fosfat $\left(\mathrm{PO}_{4}\right)$ pada daerah budidaya rumput laut yaitu $50 \mathrm{~m}, 500 \mathrm{~m}$ dan $1000 \mathrm{~m}$ dari muara sungai menunjukkan perbedaan yang signifikan. Hasil uji laboratorium menunjukkan bahwa jarak tanam $50 \mathrm{~m}$ dari muara mengandung rata-rata $\mathrm{PO}_{4} 0,0025 \mathrm{ppt}$, jarak tanam $500 \mathrm{~m}$ dari muara mengandung rata-rata $\mathrm{PO}_{4} 0,00293 \mathrm{ppt}$, dan jarak tanam $1000 \mathrm{~m}$ dari muara mengandung rata-rata $\mathrm{PO}_{4} 0,00207$ ppt. Pada umumnya dalam perairan alami kandungan fosfat terlarutnya tidak lebih dari 0,1 ppt, kecuali pada perairan penerima limbah rumah tangga dan industri tertentu serta limpahan air dari daerah pertanian yang umumnya mengalami penumpukan fosfat, Effendi (2003).

Hal ini menunjukkan bahwa ketiga lokasi tersebut ideal untuk budidaya rumput laut. Kisaran $\mathrm{PO}_{4}$ yang terukur selama penelitian di ketiga lokasi tersebut masih dalam kisaran yang layak sehingga mampu mendukung pertumbuhan rumput laut. Hasil analisis sidik ragam fosfat menunjukkan adanya pengaruh sangat nyata pada perlakuan jarak tanam $50 \mathrm{~m}, 500 \mathrm{~m}$ dan $1000 \mathrm{~m}$ dari muara sungai. Keadaan ini didukung oleh data kualitas air selama penelitian yang cukup mendukung fosfat air laut.

\section{e. Suhu}

Penelitian yang telah dilakukan menunjukkan suhu yang paling berpengaruh terhadap produksi rumput laut terdapat pada jarak tanam $50 \mathrm{~m}$ dan $500 \mathrm{~m}$ dari muara sungai (Gambar 8). Suhu optimum perairan berkisar $26^{\circ} \mathrm{C}$ 29०C (Dahuri, 2001), sehingga suhu memberikan kualitas air yang baik terhadap pertumbuhan rumput laut yang telah diteliti. 


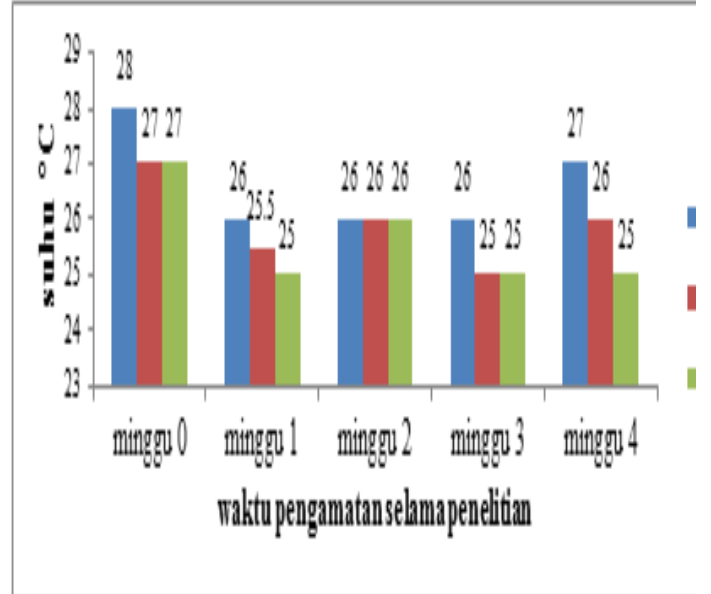

Gambar 8. Hasil pengukuran suhu air
laut

Suhu pada daerah budidaya rumput laut yaitu $50 \mathrm{~m}, 500 \mathrm{~m}$ dan 1000 $\mathrm{m}$ dari muara sungai tidak menunjukkan perbedaan yang signifikan. Hasil uji pada lokasi penelitian menunjukkan bahwa jarak tanam $50 \mathrm{~m}$ dari muara mengandung rata-rata suhu $26,6^{\circ} \mathrm{C}$, jarak tanam $500 \mathrm{~m}$ dari muara mengandung rata-rata suhu $26^{\circ} \mathrm{C}$, jarak tanam $1000 \mathrm{~m}$ dari muara mengandung rata-rata suhu $25,6^{\circ} \mathrm{C}$. Dahuri (2001), menyatakan bahwa di perairan nusantara kita suhu air laut umumnya berkisar antara $28-38^{\circ} \mathrm{C}$. Suhu Permukaan Laut (SPL), Indonesia secara umum berkisar antara $26-29^{\circ} \mathrm{C}$ karena perairan Indonesia dipengaruhi oleh angin musim, maka sebab SPL-nya pun mengikuti perubahan musim. Hal ini menunjukkan bahwa lokasi yang ideal untuk melakukan budidaya rumput laut adalah pada jarak tanam $50 \mathrm{~m}$ dan 500 $\mathrm{m}$ dari muarah sungai. Kisaran suhu yang terukur selama penelitian di kedua lokasi tersebut masih dalam kisaran yang dapat ditolerir sehingga mampu mendukung pertumbuhan rumput laut.

Hasil analisis sidik ragam suhu menunjukkan adanya pengaruh sangat nyata pada perlakuan jarak tanam $50 \mathrm{~m}$ dan $500 \mathrm{~m}$ dari muara sungai. Keadaan ini didukung oleh data kualitas air selama penelitian yang cukup mendukung suhu air laut.

\section{f. Kekeruhan}

Tingkat kekeruhan yang dihasilkan pada penelitian yang telah dilakukan menunjukkan pebedaan pada setiap jarak tanam dalam penentuan kualitas air. Data kekeruhan air disajikan pada Gambar 9. Hasil penelitian terhadap tingkat kekuruhan air selama penelitian menunjukkan nilai kekeruhan terbaik terletak pada perlakuan jarak tanam 500 $\mathrm{m}$ dari muara sungai, pada pengamatan minggu ke-2.

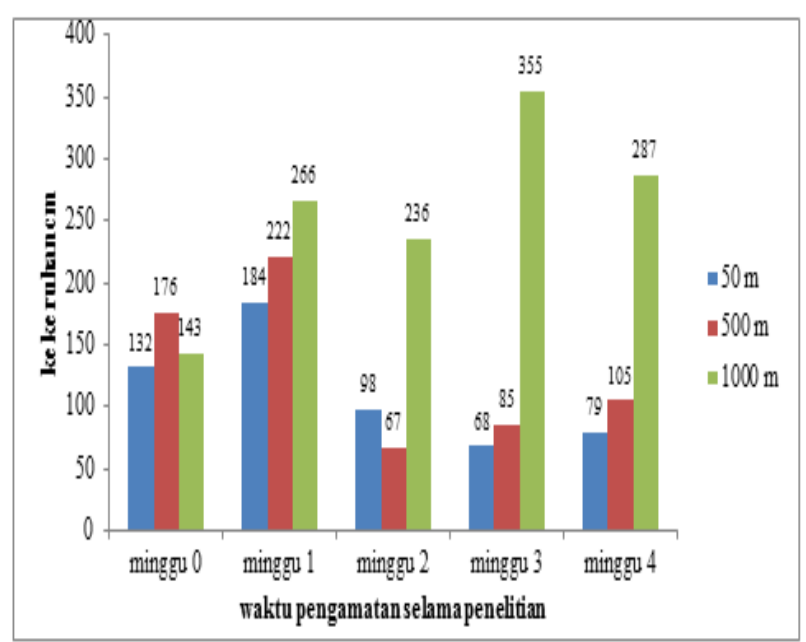

\section{Gambar 9. Hasil pengukuran kekeruhan air laut}

Kekeruhan pada daerah budidaya rumput laut yaitu $50 \mathrm{~m}, 500 \mathrm{~m}$ dan 1000 $\mathrm{m}$ dari muara sungai menunjukkan perbedaan yang signifikan. Hasil uji laboratorium menunjukkan bahwa jarak tanam $50 \mathrm{~m}$ dari muara mengandung rata-rata kekeruhan $112,2 \mathrm{~cm}$, jarak tanam $500 \mathrm{~m}$ dari muara mengandung rata-rata $131 \mathrm{~cm}$, dan jarak tanam 1000 $\mathrm{m}$ dari muara mengandung rata-rata 257,4 cm. Selanjutnya Walhi (2006), 
menyatakan bahwa kekeruhan standar untuk lingkungan rumput laut sebesar 20 ppt. Hal ini dikarenakan pada daerah budidaya terdapat aktifitas masyarakat dalam hal budidaya rumput laut dan penangkapan dengan menggunakan perahu dayung yang bisa sampai ke dasar perairan dan menyebabkan pasir dari dasar perairan naik ke permukaan. Faktor lainnya yaitu karena sedimentasi, dimana pada budidaya rumput laut terkadang ada rumput laut yang mati dan bisa menjadi material-material yang tersuspensi.

Hal ini menunjukkan bahwa ketiga lokasi tersebut ideal untuk melakukan budidaya rumput laut. Hasil analisis sidik ragam kekeruhan menunjukkan adanya pengaruh sangat nyata pada perlakuan jarak tanam 50 m, $500 \mathrm{~m}$ dan $1000 \mathrm{~m}$ dari muara sungai. Keadaan ini didukung oleh data kualitas air selama penelitian yang cukup mendukung kekeruhan air laut.

\section{KESIMPULAN}

Lokasi penanaman rumput laut paling sesuai adalah pada jarak tanam $500 \mathrm{~m}$ dari muara sungai dengan nilai produksi rata-rata tertinggi sebesar $88500 \mathrm{~g}(88,5 \mathrm{~kg})$ sedangkan kualitas air yang paling berpengaruh terhadap pertumbuhan dan produksi rumput laut yaitu salinitas, $\mathrm{pH}$, suhu, kekeruhan, fosfat dan oksigen terlarut.

\section{DAFTARPUSTAKA}

Akib, A., M. Litaay.,Ambeng., dan M.Asnady. 2015. Kelayakan Kualitas Air Untuk Kawasan Budidaya Eucheuma cottoni Berdasarkan Aspek Fisika, Kimia dan Biologi di Kabupaten Kepulauan Selayar. Jurnal
PesisirdanLautTropis. Vol.1 No. 1: 25-36

Aslan, M. 1999. Budidaya Rumput Laut. Kanisius. Yogyakarta.

Dahuri, R. 2001. Pengelolaan Sumber Daya Wilayah Pesisir dan Lautan Secara Terpadu. PT. Pradnya Paramita. Jakarta.

Dinas Perikanan Propinsi Sulawesi Selatan. 1998.Kementerian Kelautan dan Perikanan. www.pelabuhanperikanan.co.id..

Effendy, H. 2003. Telaah Kualitas Air. Kanisisus. Yogyakarta.

Fardiaz, S. 1992. Polusi Air dan Udara. Kanisisus. Yogyakarta.

Joppy, D. M., Kolopita, M. E. F., dan A. Rahman. 2015. KondisiLingkungan Perairan PadaLahan BudidayaRumputLaut KappaphycusalvareziiDiDesaJayak arsaKabupaten MinahasaUtara. JurnalBudidayaPerairanJanuari201 5. Vo. 2 No. 1: 172-186

Kamlasi, Y. 2008. Kajian Ekologi dan Biologi untuk Pengembangan Budidaya Rumput Laut (Eucheuma cottoni) di Kecamatan Kupang Barat Kabupaten Kupang Propinsi Nusa Tenggra Timur. [Tesis]. Bogor: Program Pascasarjana, Institut Pertanian Bogor.

Laporan Akuntabilitas Kinerja. 2013. Kementerian Kelautan dan Perikanan. www.pelabuhanperikanan.co.id.. 
A. Ichsan Nur , Et al / Jurnal Pendidikan Teknologi Pertanian, Vol. 2 (2016) : 27-40

Patang dan Yunarti. 2009. Pengaruh Berbagai Metode Budidaya Dalam Meningkatkan Produksi Rumput Laut. Pangkep.

Soesono. 1989. Limnology. Direktorat Jenderal Perikanan. Departemen Pertanian. Bogor

Sulistijo. $1980 . \quad$ Potensi dan Pengembangan Budidaya. Perairan di Indonesia. Proyek Penelitian Potensi Sumberdaya Ekonomis. LON-LIPI, Jakarta.

Tambaru, R. dan F. Samawi. 1996. Beberapa Parameter Kimia Fisika Air di Muara Sungai Tallo Kota Makassar. TORANI Universitas Hasanuddin. Makassar.

Walhi. 2006. Dampak Lingkungan Hidup Operasi Pertambangan Tembaga dan Emas Freeport-Rio Tinto di Papua. WALHI. Jakarta Indonesia. 